\title{
A INTERPRETAÇÃO GEOGRÁFICA DA LOCALIZAÇÃO DOS LIXÕES MUNICIPAIS
}

\author{
Bruno Batista da Cunha \\ (Mestrando em Geografia - PPGEO/UFPA - brunocunha@ufpa.br)
}

\section{Resumo}

Os rebatimentos das relações conflituosas do capitalismo têm sido abordados com ampla freqüência nas pesquisas geográficas, contudo o lixo, problema reincidente em qualquer questão urbanística, não tem merecido a devida atenção da Geografia. Com o lixo, uma abordagem ambiental verdadeiramente alijada dos estudos da Geografia Humana. Este artigo relatará um gene de caráter ambiental como sua prima motivação; abordará a formação social do espaço e como o lixo participa deste processo num contexto histórico-geográfico; tentará justificar a localização dos lixões a céu aberto no espaço urbano, bem como qualificálo tal objeto citadino; por fim, abordará questão ambiental intrínseca ao tema, seguida das conclusões do autor.

Palavras-chaves: Lixo; Espaço urbano; questão ambiental.

\section{Abstract \\ THE GEOGRAPHICAL INTERPRETATION OF THE LOCATION OF THE MUNICIPAL GARBAGE DUMPS}

The expressions of the conflicts' relations of the capitalism have been approached with broad frequency in the geographical researches, however the trash, backsliding problem in any town planning question, has not deserved the duty attention of the geography. With the trash, an environmental approach really released of the studies of the Human Geography. This article will relate a gene of environmental character as its first motivation; will approach the social formation of the space and how the trash participates of this trial in a historical-geographical context; will try to justify the location of the garbage dumps in the urban space and how to qualify it such object of the city; finally, will approach inherent environmental question to the subject, followed by the conclusions of the author.

Key - words: Garbage; Urban Space; Ambient Question 


\section{1 - Introdução}

Este documento nasce de uma sugestão de Arlete Rodrigues (1998:63) de incorporar a dinâmica ambiental aos estudos da produção social do espaço e sua complexidade, na condição de categoria geográfica. Os lixões municipais caracterizam uma problemática sócioespacial de cunho ambiental, daí a proposição, neste artigo, de sugerir uma interpretação para a questão da ocorrência e da localização dos mesmos, sob um olhar geográfico, a fim de enriquecer a temática, articulando informações sobre como a localização dos lixões municipais ser oriunda de relações sociais entre classes e objetos de ações de formação sócioespacial que ratificam e conduzem às diferenciações inerentes ao capitalismo, seja pelo excedente de pobreza que se vale dos lixões como meio de vida, seja pelas ações de desigualdade efetuadas pelo Estado.

\section{2 - Considerações sobre o espaço urbano e a formação sócio-espacial}

A Geografia é uma ciência social e, por conseguinte, estuda a sociedade (CORRÊA, 2003). Todavia, há que se diferenciar de outras ciências sociais, e o faz através do espaço. Isto é, a organização espacial viabiliza o estudo da sociedade, pela Geografia. Entende-se que a organização espacial é o conjunto de objetos fixos, distribuídos ou organizados em razão de determinada lógica. Nosso entendimento é que tal lógica é fruto do trabalho social.

Assim, o espaço é produto das relações. Todavia, a organização espacial ou, segundo Corrêa (2003), espaço geográfico, espaço social, espaço socialmente produzido, ou simplesmente, espaço, é onde as relações são materializadas, o que lhe confere a característica de meio para esta materialização, isto é, para a produção das necessidades presentes.

Quanto ao espaço urbano, Corrêa (2005) confere algumas considerações. Diz que no capitalismo, as diferenças sociais no que se dá ao "acesso aos bens e serviços produzidos socialmente" (p. 29) são muitos grandes. Foca a exclusão ao aspecto habitacional, sem contudo, esquecer de correlacioná-lo à subnutrição, às doenças, ao baixo nível de escolaridade, ao desemprego ou ao emprego mal-remunerado. Ribeiro (1997) parece concordar ao dizer que o preço da terra é o "mecanismo econômico responsável pela constituição do espaço urbano e pela segregação social na cidade”. Já para Santos (1994), o fato da população não ter acesso aos bens e serviços essenciais supracitados, "fomenta a expansão da crise urbana". Milton Santos continua dizendo que a pobreza é, também, fato do modelo espacial, o que leva a cidade a ser entendida como "criadora de pobreza". Aí, o espaço é condição. 
Neste contexto, impossível visualizar o espaço, de forma absoluta, como que o recipiente dos fenômenos sociais, resumido à descrição; nem tampouco uma realidade material que dependa da existência de objetos que se relacionam entre si, analisado primeiramente sob o foco de uma homogeneidade idealizada. O espaço geográfico contém e está contido em várias relações conflituosas e é dimensionado e avaliado por suas concepções, representações e práticas.

Muito embora possam ser utilizadas como bases teóricas, de caráter cronológico, ainda assim, refutáveis, idéias de formação do espaço social como a delimitação entre círculos concêntricos que definem localização de classes distintas (espaço absoluto) ou, ainda, esta idéia incrementada pelos "eixos de ligação" (espaço relativo), nada mais são que metodologias geométricas que analisam as disposições sociais no espaço urbano de forma descritiva, com observância nos resultados, alijando-se, totalmente, de uma interpretação analítica profícua dos processos geradores destes sistemas distintos, num espaço fragmentado.

Capel (1989) nos lembra que a força da Escola de Sociologia de Chicago, desde o final do Século XIX, fez com que a Geografia fosse configurada como uma ciência auxiliar, o que, por muito tempo, subverteu conceitos geográficos à uma interpretação sociológica, não necessariamente equivocada, mas indevidamente postada sobre a Geografia e não ladeada pela ciência geográfica, que acabou por provocar, na utilização da Ecologia como um parâmetro de estudo do comportamento social, inclusive nas cidades, um paradigma inexorável. Isto redundou na teoria dos círculos concêntricos, já que, como animais, os seres sociais (humanos) delimitariam seus territórios, conforme sua espécie, gênero ou família, isto é, conforme sua classe social.

Os eixos de ligação que justificariam os movimentos entre as classes e a idéia economicista simplista de que a renda definiria os pares sociais não observam o que provoca tanto estes movimentos, quanto às diferenciações aquisitivas e como se refletem no espaço urbano.

Para Harvey (1980:81),

\footnotetext{
"Os geógrafos têm [...] acompanhado os economistas num estilo de pensamento, no qual as questões de distribuição são deixadas de lado (principalmente porque elas envolvem desagradáveis juízos éticos e políticos), enquanto os padrões de localização "ótimos" eficazes são determinados a partir de uma distribuição particular de renda hipotética".
} 
Esse autor entende que a teoria da localização está mal dirigida ao focar-se na eficácia, em detrimento do custo social, em uma visão de curto prazo. David Harvey prossegue concluindo que os grupos ou indivíduos que sofrem os impactos deste custo social serão uma "fonte de ineficiência a longo prazo".

Isto exposto parece-nos já tácito que o modelo de produção do espaço está vinculado ao domínio e à influência do modo de produção capitalista e da divisão territorial do trabalho. Assim, o capital comanda o trabalho humano, que, ao longo do tempo, resulta na organização espacial, e como ação do capital não é uniforme sobre tempo e espaço, com natureza apropriada em concentrações e centralizações diferentes de investimentos, o desenvolvimento espacial é absolutamente desigual.

\section{3 - A problemática do lixo em um breve contexto histórico-geográfico}

Segundo Mazzini (2003: 219), lixões são locais para a disposição de resíduos domiciliares e públicos "a céu aberto, sem nenhum critério técnico com relação à escolha da área e à implantação e operação da disposição; causa poluição da água, do ar e do solo, além de poluição visual". Quando Santos (1996) ${ }^{1}$ apud Fonseca e Moraes (2006) associa diretamente a eficácia da ação à adequação do objeto, é fácil perceber que o lixão é um objeto inadequado, resultado de uma ação irretorquivelmente ineficaz.

Nenhuma interpretação sob a temática pode ser iniciada sem que nos reportemos ao espaço socialmente produzido e, complementarmente, ao tempo (seu par dialético), seguido da gestão. "Para compreender a complexidade da dinâmica da produção social do espaço, não podemos esquecer o tempo histórico e a natureza" (RODRIGUES, 1998, p. 64) e essa produção social do espaço, organizada pelo homem, é o que Corrêa (2003) chama de espaço geográfico.

À luz do espaço geográfico e sua organização social, onde se materializam os movimentos do capital e se refletem as desigualdades, verificamos as condições, manifestadas nas relações sociais, que direcionam um processo decisório ${ }^{2}$, e quase que inevitável, de localização dos lixões urbanos.

Convém lembrar que a produção do lixo urbano confere ao tempo o caráter acumulativo do problema, e, processual que é, passa a depender mais dos movimentos de

\footnotetext{
${ }^{1}$ SANTOS, Milton. A natureza do espaço. Técnica e tempo, razão e emoção. São Paulo: Hucitec, 1996.

${ }^{2} \mathrm{O}$ processo decisório é uma modelagem administrativa onde a gestão, resumidamente, identifica o problema e as oportunidades, avalia certezas, riscos e incertezas e dentro de um algoritmo específico, implementa e monitora uma decisão administrativa.
} 
geração e, mormente, seus eventos majoradores, que simplesmente sua geração média diária ${ }^{3}$.

Essa acumulação temporal impressa no espaço urbano, por sua caracterização variável com fonte geradora, atribui impactos sobre o meio ambiente e a saúde coletiva, nos mais diversos níveis e intensidades.

O lixo é gerado ao longo de toda a existência humana, mas somente a produção industrial escalonada forneceu importância a uma variável até então minimamente considerada: a biodegradabilidade. Antes da modernidade, mesmo sempre existindo, o lixo era um problema contornável por suas características majoritariamente orgânicas e assimiláveis pelo corpo receptor. O tempo de acumulação, portanto, passa a ser significativo na análise ambiental, a partir da modernidade. Seguindo, então, uma sugestão conceitual registrada por Santos $(1978)^{4}$ apud Sposito (2003:99) de que a produção do conhecimento geográfico deve analisar "as relações entre os períodos históricos e a organização espacial", podemos afirmar que o espaço socialmente produzido e o acúmulo temporal do problema, no caso da nossa análise, se originam, historicamente, nos tempos modernos.

\section{4 - A localização dos lixões no espaço urbano}

Para Damiani (2003), o urbano é um dos "principais investimentos a mover a acumulação de capital". Isto pode ser complementado pelos conceitos de fragmentação e articulação que Corrêa (2005) atribui ao espaço urbano. Fragmentação porque o espaço urbano é o conjunto variado de usos da terra e, articulação porque cada parte do espaço urbano possui relações espaciais com as demais, mesmo que em intensidades e freqüências distintas.

Ribeiro (1997) lembra que "historicamente, o Estado tem assumido o papel de produtor e gestor desses elementos não-rentáveis do valor de uso complexo, sendo este o fundamento do que se convencionou chamar de planejamento urbano". Sem aprofundamento, contudo para dar coerência à assertiva, "valor de uso complexo" é, como esse autor define, a representação da cidade na essência da contradição da urbanização.

Frente à gestão, a localização dos lixões é definida por aspectos geográficos e administrativo-financeiros. É importante, neste sentido, a distância. Esta variável geográfica atribui à modelagem do processo decisório, uma ponderação consideravelmente grande, pois é

\footnotetext{
${ }^{3}$ A geração média diária é importante para o dimensionamento dos serviços de limpeza pública e não deve ser alijada do processo geométrico e logístico da geração de lixo, contudo é extremamente reducionista para que sejam avaliadas as relações existentes nos processos sociais de produção e consumo que redundam na geração do lixo urbano.

${ }^{4}$ SANTOS, Milton. Por uma geografia nova. São Pulo: Hucitec, 1978
} 
importante que, fisicamente, com mensuração matemática, a distância dos lixões seja mínima em relação às periferias e, máxima, em relação às áreas nobres (qual seja o desenho da cidade). Os lixões, portanto, não podem se avizinhar às áreas centrais das cidades, contudo não podem distar tanto do centro de operações ${ }^{5}$. Outra variável importante é a pobreza. Lixões se encaminham para a pobreza e a pobreza se encaminha para os lixões. O poder público municipal decide, portanto, pelo bem de que possui bens, em detrimento da classe pobre, pois os lixões compõem-se, paisagisticamente, em aparência, muito mais com as portas das periferias. Isto se dá porque a municipalidade se cega às relações que os justificam, não percebendo, então, a essência que permeia sua decisão. Corrêa (2003:66) nos ajuda a concluir quando diz que “o Estado age espacialmente de modo desigual”. Harvey (1980:99) observa solução na proporcionalidade entre os mecanismos institucional, organizacional, político e econômico a as perspectivas dos territórios menos favorecidos. Todavia, não há interesse da gestão em suprir carências de forma tão efetiva.

Sendo os lixões uma paisagem essencialmente caracterizada, de forma negativa, nos aspectos sanitário, de bem-estar e estético, social e econômico, parece-nos inevitável que estejam em localizações de menor composição orgânica do espaço ${ }^{6}$, portanto nas áreas periféricas e desconectadas (ou desconcentradas) dos investimentos de capital.

Pesadas as variáveis, difícil não deduzir que os lixões estarão estabelecidos nas periferias.

A bem da verdade, muitos deles, ao iniciar operação, distavam mais das habitações mais próximas, pois primavam por um cercado verde natural que escondesse a sujeira e facilitasse a prática da queima. Mas o inchaço populacional das periferias não-assistidas os aproximou demais (população e lixo). Como já visto, a pobreza migra para o lixão e ali estabelece sustentação, inclusive habitacional, em uma dinâmica espacial que acaba por suprimir a eventual (anterior) existência de um cercado natural.

Os lixões passam a ser invadidos por aqueles que acabaram por optar por sobreviver do lixo e no lixo.

\section{5 - Lixões, um objeto de ações}

\footnotetext{
${ }^{5}$ A administração pública municipal, via de regra, estabelece que $10 \mathrm{~km}$ é uma distância economicamente viável para o transporte de resíduos não implicar em prejuízo operacional.

${ }^{6} \mathrm{O}$ conceito de composição orgânica do capital está relacionado, proporcionalmente, ao desenvolvimento das forças produtivas e aos gastos com os meios de produção. Fatores estes, referendados em menor escala nas áreas pobres.
} 
Não há interesse neste trabalho em analisar o circuito inferior da economia ${ }^{7}$ atuante nos lixões, bem como as relações e percepções do grupo socialmente excluído que labora sob condições subumanas. O foco geográfico é, por enquanto, simplesmente, locacional. É assim que analisamos a inclusão dos lixões nas "localizações pontuais ou em áreas dos meios necessários às operações de produção, como fábricas, minas e campos" que Coraggio (1979) ${ }^{8}$ apud Corrêa (2003: 56) cita como um dos fatores de caráter repetitivo na organização espacial capitalista.

A localização dos lixões, quando estes começaram a ser "formalizados", é resultado de um processo construtivo ${ }^{9}$ mais que de um processo produtivo ${ }^{10}$. Hoje, este quadro é rigorosamente invertido, desde a apropriação da natureza para a instalação do neoextrativismo urbano em condições laborais talvez só comparáveis à primeira revolução industrial, até a formação sócio-espacial, resultado das relações, meio de sua produção e retroalimentada pela força de produção.

Ao fixar no solo os seus objetos, frutos do trabalho social e vinculados às suas necessidades, um grupo possibilita que as atividades desempenhadas por estes alcancem um período de tempo mais ou menos longo, repetindo, reproduzindo as mesmas. Nestas condições, o grupo social se reproduz, porque a reprodução das atividades ligadas às suas necessidades viabiliza o próprio".(CORRÊA, 2003: 55).

Conclusivamente, os lixões são concebidos, embrionariamente, no seio da gestão municipal, como objeto desta ação gestionária. É objeto, também, de ações exploradoras da pobreza que se reproduzem no neo-extrativismo urbano, onde o pobre - excedente e interessante ao modo de produção capitalista - garimpa um recurso reciclável como nova matéria-prima à (re)produção objetivada no capitalismo, sob condições monetárias extremamente vantajosas aos adquirentes. É objeto, ainda, reproduzido pelas ações de subsistência financeira e alimentar a que se sujeita o grupo social excluído que dele depende, pois entende que a existência de lixões é fonte para a supressão das próprias necessidades.

\footnotetext{
${ }^{7}$ Santos (1978) apud Corrêa (2003) define - e nós simplificamos - o circuito inferior da economia, pelas atividades informais exercidas pela classe de menor poder aquisitivo.

${ }^{8}$ CORAGGIO, José Luís. Considerações técnico-metodológicas sobre as formas sociais da organização do espaço e suas tendências na América Latina. Salvador, 1979.

${ }^{9}$ Baseamo-nos em Rodrigues (1998) para definir processo construtivo como uma transformação geométrica, com fulcro, simplesmente nas engenharias e na arquitetura, sem variáveis sociais.
} 


\section{6 - A questão ambiental}

Esta contextualização dá forças à sugestão de Rodrigues (1998) de aproximar as abordagens críticas da Geografia ao seu ramo físico, pois entende que se a dimensão natureza for alijada de análises como estas, a Geografia permanecerá "viúva do espaço" ou perderá “(novamente) o seu próprio espaço" (p. 67), isso, caso não alcance a integração destas categorias: meio ambiente e espaço.

As classes ricas só são capazes de evidenciar esta questão ambiental - sob o enfoque urbano e de forma reducionista - quando há lapsos na coleta, não lhes interessando, de fato, onde e sob de que forma está sendo depositado o lixo urbano, contanto que esteja distante de seu mapa urbano diário. Já para as classes pobres, desempregados ou mal-remunerados, os lixões tornam-se fontes de renda única ou alternativa, casa, fonte de alimentação e recurso derradeiro ou possibilidade laboral primeira; como se se utilizassem de uma nova natureza a ser consumida por suas necessidades elementares.

Ambas as percepções minimizam o aspecto ambiental inerente. As áreas dos lixões são degradadoras eficientíssimas. A localização dos lixões confere apropriação de área não explorada, cuja recuperação, em média, só poderá ser contemplada com um fim social de uso após dez anos de monitoramento e verificação de condições adversas contornáveis.

As ações ambientais, hoje, são majoritariamente corretivas sob o evento ambiental, porém, devem ser preventivas sob as intervenções relacionais que justificam os lixões. A quem interessa? Não há força de lei, forma clara do comprometimento estatal com o modo de produção, devidamente bem representado nas instâncias legislativas ${ }^{11}$. Não há delírio capitalista em se desvencilhar de um excedente de pobreza (mão-de-obra) a custo muito barato que oferece-lhe ganhos financeiros e institucionais mascarados na febre da reciclagem. Não há, por força das condições impostas, razão para que catadores de materiais recicláveis saiam de lixões e retornem à vida que os levou aos lixões. O meio ambiente, portanto, como em muitos casos, é evidenciado como uma externalidade econômica ${ }^{12}$ e por essa economia são determinadas, sua apropriação (espaço), sua exploração (tempo e gestão) e sua conservação (reserva).

\footnotetext{
${ }^{10}$ Ainda em Rodrigues (1998), temos que processo produtivo culmina em transformações oriundas das relações sociais no espaço.

${ }^{11}$ Esta afirmação nasce da representação legislativa que as classes economicamente dirigentes possuem, e que, lhe garantem um poder político capaz de garantias legais para a promoção da acumulação de capital.

12 Externalidade econômica advém da extrapolação do veio monetário da economia, portanto da expansão das fronteiras econômicas. Um novo paradigma de avaliação quantitativa e qualitativa, em grande parte das vezes, com impossibilidades de valorização, senão subjetiva.
} 


\section{7 - Conclusões}

- Lixões estão repletos de relações. É representação do espaço, fruto da decisão institucional; é, também, espaço das representações, onde catadores de materiais recicláveis se vêem, diariamente, mesmo que topofobicamente, estabelecendo uma nova forma de resistência, sem contudo deixar de se aprisionar à (re)ciclagem dos processos produtivos, onde são motrizes inicias neste neo-extrativismo que é a catação do lixo; é objeto definido e reproduzido por ações relacionais.

- Trata-se de fixo, resultado e condição de movimentos de capital e de reprodução de desigualdades. Uma singularidade urbana inóspita e ímpar, capaz de associar degradações ambiental e humana em escala local de repetição continental que parece permear o cotidiano de forma a cegar-nos contra suas evidências adversas.

- O atual clamor por aterros sanitários ao invés de lixões, gritos troantes de grupos sociais e técnicos engajados na solução ambiental, na reconfiguração espacial e no caráter sociológico do tema, pode e deve ocasionar o que Santos (1996) chama de redefinição da ação sobre um objeto que também se redefine. Mas, de qualquer forma, não é simples, posto que revolucionário.

\section{8 - Bibliografia}

CAPEL, Horacio. Geografia humana y ciências sociales: una perspectiva histórica. 3. Ed. Barcelona: Montesinos,139p. (Biblioteca de Divulgación Temática 38). 1989.

CORRÊA, Roberto Lobato. Região e organização espacial. 7. Ed. São Paulo: Ática. p. 51-84. (Série Princípios 53). 2003.

CORRÊA, Roberto Lobato. O espaço urbano. 4. Ed. São Paulo: Ática, p. 96. (Série Princípios 174). 2005.

DAMIANI, Amélia. O urbano no mundo da mercadoria. In: CARLOS, Ana Fani A. e LEMOS, Amália (Orgs.). Dilemas urbanos. Novas abordagens sobre a cidade. São Paulo: Contexto, p. $367-369.2003$.

FONSECA, Jean e MORAES, Mauro. A natureza do espaço: técnica e tempo, razão e emoção. Belém: Mestrado em Geografia - UFPA, 2006. Resenha de: SANTOS, Milton. A natureza do espaço: técnica e tempo, razão e emoção. São Paulo: Hucitec, 7p. 1996. HARVEY, David. A justiça social e a cidade. São Paulo: Hucitec, p. 81- 102. 1980. MAZZINI, Ana Luiza D. de Amorim. Dicionário educativo de termos ambientais. Belo Horizonte: Conselho Regional de Química - MG, 384p. 2003. 


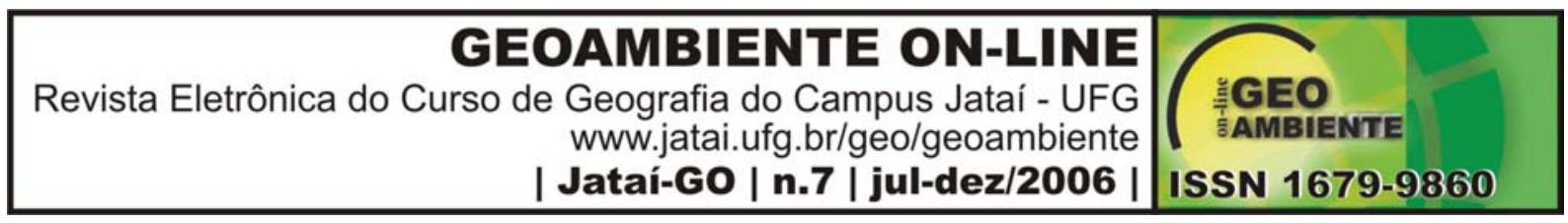

RODRIGUES, Arlete Moysés. Produção e consumo do e no espaço: problemática ambiental urbana. São Paulo: Hucitec, 239 p. 1998.

RIBEIRO, L. C. de Queiroz. Dos cortiços aos condomínios fechados: as formas da produção de moradias na cidade do Rio de Janeiro. Rio de Janeiro: Civilização Brasileira: IPPUR, UFRJ:FASE, p 37-101. 1997.

SANTOS, Milton. A urbanização brasileira. São Paulo: Hucitec, 157p. 1994.

SPOSITO, Eliseu. Conceitos. In: SPOSITO, Eliseu. Geografia e Filosofia: contribuição para o ensino do pensamento geográfico. São Paulo: UNESP, p 87-119. 2004. 